\title{
Association of temperature humidity index during summer with haematological parameters in native and crossbred goats of Kerala*
}

\author{
Debia Yamin $^{1 * *}$, V. Beena ${ }^{2}$, V. Ramnath ${ }^{3}$, R. Thirupathy Venkatachalapathy ${ }^{4}$ \\ and Aziz Zarina ${ }^{5}$ \\ Department of Veterinary Physiology, College of Veterinary and Animal Sciences, \\ Mannuthy, Thrissur- 680 651, Kerala Veterinary and Animal Sciences University, Kerala, India
}

Citation: Debia, Y., Beena, V., Ramnath, V., Venkatachalapathy, T. R. and Zarina, A. 2021. Association of temperature humidity index during summer with haematological parameters in native and crossbred goats of Kerala. J. Vet. Anim. Sci. 52(3): 222-227

DOI: https://doi.org/10.51966/jvas.2021.52.3.222-227

Received: 14.01.2021

Accepted: 08.03.2021

Published: 30.09 .2021

\begin{abstract}
The study was conducted to investigate the association of temperature humidity index (THI) during summer with haematological responses in Malabari, crossbred and Attappady goats of Kerala. The research work was conducted at University Goat and Sheep Farm, KVASU, Mannuthy, Thrissur district in Kerala from March to May, 2020. In-house temperature and in-house relative humidity were measured daily at 7.00 AM, 10.00 AM, 2.00 PM and 5.00 PM. Haematological parameters such as total erythrocyte count (TEC), total leucocyte count (TLC), haemoglobin concentration (Hb), volume of packed red cells (VPRC), mean corpuscular volume (MCV) and mean corpuscular haemoglobin concentration $(M C H C)$ were analysed during $2^{\text {nd }}$, $32^{\text {nd }}$ day and $60^{\text {th }}$ day of the study. There was no significant change in TEC, VPRC levels in between the breeds and within the observed days. However, TLC were significantly increased for Malabari goats and MCHC were significantly increased in all the breeds at $32^{\text {nd }}$ day of study period. The $\mathrm{Hb}$ concentration were significantly increased in crossbred and Attappady black at $32^{\text {nd }}$ day of study period. There was a significant decrease in MCV values in $2^{\text {nd }}$ and $32^{\text {nd }}$ day for all the breeds. The study demonstrated certain altered hematological features in all the breeds under study indicating the adaptive ability of these animals during heat stress.
\end{abstract}

Keywords: Goats, thermal stress, Temperature Humidity Index, haematological parameters

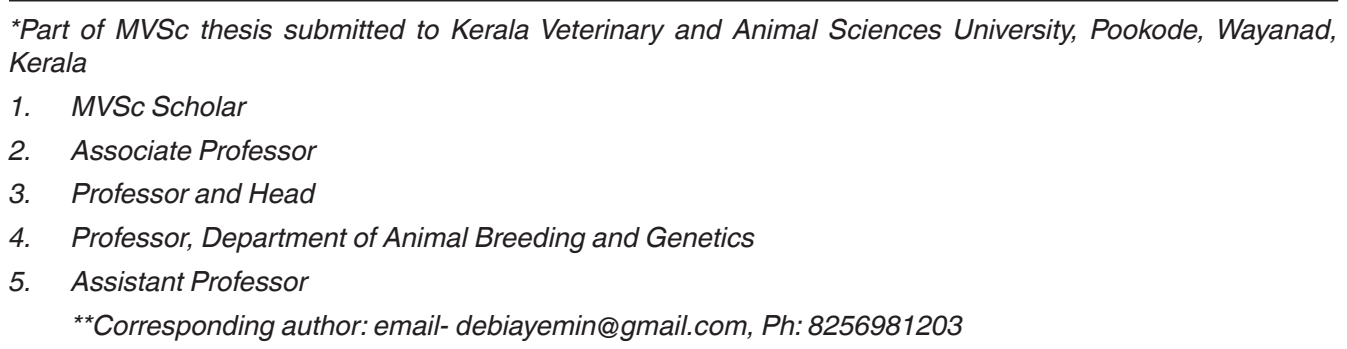

Copyright: () 2021 Debia et al. This is an open access article distributed under the terms of the Creative Commons Attribution 4.0 International License (http://creativecommons.org/licenses/by/4.0/), which permits unrestricted use, distribution, and reproduction in any medium, provided the original author and source are credited. 
India's average temperature has increased by $0.7^{\circ} \mathrm{C}$ during $1901-2018$ According to Intergovernmental Panel of Climate Change (IPCC) 2018, global warming is likely to reach $1.5^{\circ} \mathrm{C}$ in between 2030 and 2052; $1.5^{\circ} \mathrm{C}$ increase in global surface temperature will have devastating consequences on both human and animal population. The climate change has lately turned to be one of the most serious and long-standing term of considerable challenges experienced by livestock owners and farmers. In these circumstances, goat rearing has been identified as a sustainable livestock rearing system and has gained economic importance in almost all countries facing harsh climatic events frequently. Goats has the ability to cope with climate change by expressing adaptive strategies as compared to other ruminants (Silanikove, 2000) because of their lower body mass, lower metabolic requirements, ability to reduce metabolism, skillful grazing behavior and effective urea cycling (Silanikove and Koluman, 2015). The main climatic variables that impose impact on goats are high ambient temperature, high direct and indirect solar radiation, wind speed and humidity (Silanikove, 2000). Temperature humidity index (THI), a reliable indicator of stressful thermal environment could be used for measuring the heat load in animals. Goats are known for their tolerance to heat stress but they suffer from thermal stress beyond their comfort zone and environmental temperatures for goats fall in the range between $13-27^{\circ} \mathrm{C}$ (Mishra, 2009). Goat subjected to heat, would experience a transition from being ideal in its internal state and thus experience a degree of stress.

There are several phenotypic and genotypic adaptive abilities that provide goats to counter thermal stress. Identification of these adaptive capabilities in various goat breeds of Kerala would help to select the most appropriate goat breed for the future and also to identify the various management strategies to be adopted for sustainable goat farming.

Assessment of haematological parameters gives an evaluation of the health status of the animals. During periods of thermal stress there will be alteration in physiological features for maintenance of homeostasis. Assessing the severity of these alterations would give an idea about the adaptive capacity of these animals to a great extent and would also help to identify the most climate resilient goat breed suitable for hot, humid tropical climate of Kerala. Hence, this study was undertaken to assess the association of $\mathrm{THI}$ with haematological parameters in Malabari, crossbred and Attappady goats of Kerala.

\section{Materials and methods}

The research work was conducted at University Goat and Sheep Farm, Kerala Veterinary and Animal Sciences University (KVASU), Mannuthy, Thrissur district in Kerala state. Farm is located at $10^{\circ} 56^{\prime \prime} \mathrm{N}$ and $76^{\circ} 26^{\prime \prime} \mathrm{E}$ at an altitude of $2.83 \mathrm{~m}$. The period of study was 60 days from March 2020 to May 2020 during which high thermal stress was experienced Six animals each from Attappady black, Malabari and crossbred (Malabari X Saanen) female goats of eight to 12 months of age were selected and divided into three groups. All animals were apparently healthy and free from any physical abnormalities. Animals were housed in the elevated platform with corrugated roof sheet and were fed as per Indian Council of Agricultural Research (ICAR) feeding standards and provided with ad lib. water (ICAR, 2013).

Ambient temperature $\left({ }^{\circ} \mathrm{C}\right)$ and ambient relative humidity (\%) inside the shed were recorded by electronic digital logger (HOBO pro V2, Onset Computer Corporation, USA) on every alternate day of study period at 7.00 A.M, 10.00 A.M, 2.00 P.M and 5.00 P.M. Temperature Humidity Index was calculated as per livestock and poultry heat stress indices (LPHSI, 1990)

$$
\begin{aligned}
& \text { THI }=\mathrm{T}_{(\mathrm{db})}-\left\{(0.55-0.55 \mathrm{RH})\left(\mathrm{T}_{(\mathrm{db})}-58\right)\right\} \\
& \text { Where, } \\
& \qquad \mathrm{T}_{(\mathrm{db})}=\text { Dry bulb temperature }\left({ }^{\circ} \mathrm{F}\right) \\
& \mathrm{RH}=\text { Relative humidity }(\%)
\end{aligned}
$$

Blood samples were collected into vacutainers through venipuncture on days 2,32 and 60 between $11.00 \mathrm{AM}$ to 12 noon. Whole blood was collected in vacutainer containing $3.6 \mathrm{mg}$ potassium ethylene diamine tetra acetic acid salt (EDTA) for immediate haematological 
analyses. Haematological parameters like total erythrocyte count (TEC), haemoglobin $(\mathrm{Hb})$, volume of packed red blood cells (VPRC) and total leucocyte count (TLC) were estimated in whole blood using haematological analyser (Mythic 18 vet-blood analyser). The erythrocyte indices such as mean corpuscular volume (MCV) and mean corpuscular haemoglobin concentration $(\mathrm{MCHC})$ were calculated as described by Schalm et al. (1986).

\section{Statistical analysis}

Results were expressed as means $( \pm$ SE). The data obtained on various parameters were statistically analysed as per the method of Snedecor and Cochran (1994) using analysis of variance (ANOVA), repeated measures of ANOVA and Pearson's correlation method. The whole data were analysed using computerized software programme SPSS V.24.0.

\section{Results and discussion}

\section{In-house ambient temperature (IT)}

The mean in-house temperatures were highest in the month of March $\left(39.54^{\circ} \mathrm{C}\right)$ and the lowest during month of April $\left(23.91^{\circ} \mathrm{C}\right)$. Harikumar (2017) recorded the maximum interior temperature during March $\left(39.86^{\circ} \mathrm{C}\right)$ in Kerala. The in-house temperature recorded by Zarina (2016) in Thrissur was maximum during $2^{\text {nd }}$ half of March $\left(36.03^{\circ} \mathrm{C}\right)$. Jisha et al. (2021) also found that highest mean of average temperature over a period from 2011-2016 was in March in Thrissur, Kerala.

The diurnal in-house temperature when observed during the different times, the lowest was observed at $7.00 \mathrm{AM}\left(24.61^{\circ} \mathrm{C}\right)$ and the highest was at $2.00 \mathrm{PM}\left(37.54^{\circ} \mathrm{C}\right)$. Harikumar (2017), could observe highest between 2.00-3.00 PM in Thrissur and Jisha et al. (2021) found highest in-house temperature in the afternoon (around 3.00 PM) during the period of March to May at Mannuthy, Thrissur, Kerala.

\section{In-house relative humidity (IRH)}

The highest monthly mean in-house relative humidity was noticed in the month of May $(98.69 \%)$ and lowest in the month of March (37.83\%). Similar results were also recorded by Zarina (2016) and Harikumar (2017), where the interior relative humidity was maximum in May and lowest in April (when compared for a period from March - May) and explained that the higher humidity in May was due to summer rain. The relatively lesser summer rain received and higher ambient temperature in the month of March, 2020 might be the reason for the lowest relative humidity observed in this study during the month.

The mean diurnal in-house relative humidity (recorded at four times) was the highest at the time of 7.00 AM $(98.69 \%)$ and the lowest at 2.00 PM (37.83\%). The lowest value recorded at 2.00 PM might be due to the highest ambient temperature at 2.00 PM.

\section{Temperature Humidity Index (THI) (LPHSI, 1990)}

Highest THI of 88.63 was recorded in April while the lowest $\mathrm{THI}$ of 74.45 was noticed in March. This study was in accordance with Jisha et al. (2021), where the highest mean THI was recorded in April (81.74) during the period from 2011-2016 in Thrissur. The maximum THI in April (86.70) was also noted by Harikumar (2017) in Thrissur.

In the present study highest mean $\mathrm{THI}$ of 89.65 was observed at 2.00 PM and lowest THI of 75.69 at 7.00 AM. This study was in accordance with Jisha et al. (2021) who found lowest THI in the morning and highest in afternoon during the period of March to May at Mannuthy, Thrissur, Kerala.

\section{Total Erythrocyte Count (TEC)}

In the present study, the IT and THI had no effect in TEC values of breeds during the entire study period and the TEC values were within normal range. This study was similar with Hassan et al. (2013), Bhatta et al. (2014). In the latter study they found no changes in TEC levels in Beetal goats during post monsoon $\left(34.6^{\circ} \mathrm{C}\right)$ and pre monsoon $\left(42.6^{\circ} \mathrm{C}\right)$. Whereas, Alam et al. (2011), Okoruwa (2014) and Habibu et al. (2017) found increase in TEC levels in goats when ambient temperature and $\mathrm{THI}$ were high.

\section{Total Leucocyte Count (TLC)}

The total leucocyte count showed an increasing trend for Malabari goats during the study. However, no significant difference in TLC levels were observed for crossbred goats and Attappady black goats breeds. The result of the present study was in agreement with Alam et al. (2011), Banerjee et al. (2015), Olayemi et 
Table 1. Inside the animal house during March 2020 to May 2020

\begin{tabular}{|c|c|c|c|c|c|c|c|c|c|}
\hline \multirow{2}{*}{ Period } & \multicolumn{3}{|c|}{ In-house temperature $\left({ }^{\circ} \mathrm{C}\right)$} & \multicolumn{2}{c|}{ In-house relative humidity (\%) } & \multicolumn{3}{c|}{ In-house THI } \\
\cline { 2 - 10 } & Mean \pm SE & Lowest & Highest & Mean \pm SE & Lowest & Highest & Mean \pm SE & Lowest & Highest \\
\hline March & $30.88 \pm 0.08$ & 24.29 & 39.54 & $67.39 \pm 3.34$ & $\mathbf{3 7 . 8 3}$ & 92.40 & $82.64 \pm 0.82$ & 74.45 & 87.34 \\
\hline April & $30.76 \pm 0.12$ & $\mathbf{2 3 . 9 1}$ & 37.51 & $70.97 \pm 1.51$ & 52.97 & 97.84 & $83.71 \pm 0.46$ & 75.69 & 88.63 \\
\hline May & $29.56 \pm 0.14$ & 24.56 & 36.01 & $78.15 \pm 1.61$ & 58.19 & 98.69 & $82.94 \pm 0.40$ & 76.40 & 87.81 \\
\hline
\end{tabular}

Table 2. Inside the animal house during different times from March 2020 to May 2020

\begin{tabular}{|c|c|c|c|c|c|c|c|c|c|}
\hline \multirow{2}{*}{ Time } & \multicolumn{3}{|c|}{ In-house temperature $\left({ }^{\circ} \mathrm{C}\right)$} & \multicolumn{2}{c|}{ In-house relative humidity (\%) } & \multicolumn{3}{c|}{ In-house THI } \\
\cline { 2 - 11 } & Mean \pm SE & Lowest & Highest & Mean \pm SE & Lowest & Highest & Mean \pm SE & Lowest & Highest \\
\hline 7.00 AM & $27.45 \pm 0.21$ & 24.61 & 29.43 & $89.94 \pm 1.15$ & 74.16 & $\mathbf{9 8 . 6 9}$ & $80.08 \pm 0.31$ & $\mathbf{7 5 . 6 9}$ & 83.28 \\
\hline 10.00 AM & $32.18 \pm 0.26$ & 28.15 & 34.51 & $73.30 \pm 1.32$ & 57.17 & 95.68 & $85.16 \pm 0.31$ & 81.53 & 87.88 \\
\hline 2.00 PM & $34.99 \pm 0.36$ & 28.30 & 37.54 & $63.10 \pm 1.58$ & $\mathbf{3 7 . 8 3}$ & 84.74 & $87.33 \pm 0.34$ & 80.84 & $\mathbf{8 9 . 6 5}$ \\
\hline $\mathbf{5 . 0 0}$ PM & $33.56 \pm 0.27$ & 28.69 & 35.88 & $67.57 \pm 1.39$ & 44.54 & 83.74 & $86.18 \pm 0.27$ & 81.35 & 88.59 \\
\hline
\end{tabular}

Table 3. Mean \pm SE of TEC, TLC and Hb of Malabari, crossbred and Attappady black goats

\begin{tabular}{|c|c|c|c|c|c|c|c|c|c|c|}
\hline \multirow{2}{*}{$\begin{array}{l}\text { Day of } \\
\text { study }\end{array}$} & \multirow[b]{2}{*}{ THI } & \multicolumn{3}{|c|}{ 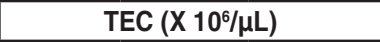 } & \multicolumn{3}{|c|}{$\operatorname{TLC}\left(\mathrm{X} \mathrm{10^{3 } / \mu \mathrm { L } )}\right.$} & \multicolumn{3}{|c|}{$\mathrm{Hb}(\mathrm{g} / \mathrm{dL})$} \\
\hline & & Malabari & Crossbred & $\begin{array}{c}\text { Attappady } \\
\text { black }\end{array}$ & Malabari & Crossbred & $\begin{array}{c}\text { Attappady } \\
\text { black }\end{array}$ & |Malabari & Crossbred & $\begin{array}{c}\text { Attappady } \\
\text { black }\end{array}$ \\
\hline $2^{\text {nd }}$ day & 82.64 & \begin{tabular}{|l|}
$11.87 \pm$ \\
0.66
\end{tabular} & \begin{tabular}{|l|}
$11.82 \pm$ \\
0.88
\end{tabular} & $\begin{array}{l}12.16 \pm \\
0.36\end{array}$ & $\begin{array}{l}9.87^{\mathrm{aA}} \pm \\
0.65\end{array}$ & $\begin{array}{l}13.58^{\text {ab A }} \\
\pm 2.07\end{array}$ & $\begin{array}{l}14.78^{\mathrm{bA}} \\
\pm 1.60\end{array}$ & $\begin{array}{l}7.87^{\mathrm{A}} \pm \\
0.33\end{array}$ & $\begin{array}{l}7.72^{\mathrm{A}} \pm \\
0.12\end{array}$ & $\begin{array}{l}8.03^{A} \pm \\
0.23\end{array}$ \\
\hline $32^{\text {nd }}$ day & 83.71 & \begin{tabular}{|l|}
$10.56 \pm$ \\
0.80 \\
\end{tabular} & $\begin{array}{l}11.55 \pm \\
0.58\end{array}$ & $\begin{array}{l}11.06 \pm \\
0.96\end{array}$ & \begin{tabular}{|l|}
$11.73^{\mathrm{a} B}$ \\
\pm 0.82 \\
\end{tabular} & \begin{tabular}{|l}
$13.12^{\mathrm{aA}} \pm$ \\
1.27
\end{tabular} & $\begin{array}{l}13.77^{\mathrm{aA}} \\
\pm 1.33 \\
\end{array}$ & $\begin{array}{l}9.37^{A} \pm \\
0.42\end{array}$ & $\begin{array}{l}9.83^{B} \pm \\
0.53^{-1}\end{array}$ & $\begin{array}{l}9.27^{\mathrm{B}} \pm \\
0.54^{-}\end{array}$ \\
\hline $60^{\text {th }}$ day & 82.94 & $\begin{array}{l}11.06 \pm \\
0.85\end{array}$ & $\begin{array}{l}11.45 \pm \\
0.42\end{array}$ & $\begin{array}{l}12.02 \pm \\
0.86\end{array}$ & $\begin{array}{l}13.97^{\text {а в }} \\
\pm 0.94\end{array}$ & $\begin{array}{l}14.58^{\mathrm{aA}} \pm \\
0.71\end{array}$ & $\begin{array}{l}11.28^{\mathrm{aA}} \\
\pm 0.67\end{array}$ & $\begin{array}{l}8.83^{A} \pm \\
0.90\end{array}$ & $\begin{array}{l}8.06^{A} \pm \\
0.21\end{array}$ & $\begin{array}{l}7.17^{A} \pm \\
0.24\end{array}$ \\
\hline
\end{tabular}

Means bearing same superscript within a row $(a-c)$ and columns $(A-C)$ do not differ significantly $(p<0.05)$ $(\mathrm{n}=6)$

Table 4. Mean \pm SE of VPRC, MCV and MCHC of Malabari, crossbred and Attappady black goats

\begin{tabular}{|c|c|c|c|c|c|c|c|c|c|c|}
\hline \multirow{2}{*}{$\begin{array}{l}\text { Day of } \\
\text { study }\end{array}$} & \multirow[b]{2}{*}{ THI } & \multicolumn{3}{|c|}{ VPRC (\%) } & \multicolumn{3}{|c|}{ MCV (fl) } & \multicolumn{3}{|c|}{ MCHC (g/dL) } \\
\hline & & Malabari & Crossbred & $\begin{array}{c}\text { Attappady } \\
\text { black }\end{array}$ & Malabari & Crossbred & $\begin{array}{c}\text { Attappady } \\
\text { black }\end{array}$ & Malabari & Crossbred & $\begin{array}{c}\text { Attappad } \\
\text { black }\end{array}$ \\
\hline $2^{\text {nd }}$ day & 82.64 & \begin{tabular}{|l|}
$26.00 \pm$ \\
1.32 \\
\end{tabular} & \begin{tabular}{|l|}
$26.45 \pm$ \\
1.66 \\
\end{tabular} & \begin{tabular}{|l|}
$26.48 \pm$ \\
0.89 \\
\end{tabular} & \begin{tabular}{|l|}
$22.20^{\mathrm{A}}$ \\
\pm 0.22 \\
\end{tabular} & \begin{tabular}{|l|}
$22.70^{\mathrm{A}} \pm$ \\
0.93 \\
\end{tabular} & $\begin{array}{l}21.77^{\mathrm{A}} \pm \\
0.61 \\
\end{array}$ & \begin{tabular}{|l|}
$30.33^{\mathrm{A}}$ \\
\pm 1.71 \\
\end{tabular} & $\begin{array}{l}29.56^{\mathrm{A}} \pm \\
1.27 \\
\end{array}$ & \begin{tabular}{|l|}
$30.45^{\mathrm{B}} \pm$ \\
0.99 \\
\end{tabular} \\
\hline $32^{\text {nd }}$ day & 83.71 & $\begin{array}{l}25.26 \pm \\
1.63\end{array}$ & \begin{tabular}{|l|}
$26.75 \pm$ \\
1.76
\end{tabular} & \begin{tabular}{|l}
$25.38 \pm$ \\
2.04
\end{tabular} & $\begin{array}{l}24.02^{\mathrm{A}} \\
\pm 0.44\end{array}$ & $\begin{array}{l}24.08^{\mathrm{A}} \pm \\
0.31\end{array}$ & $\begin{array}{l}23.80^{B} \pm \\
0.28\end{array}$ & \begin{tabular}{|l|}
$37.60^{\mathrm{B}}$ \\
\pm 2.27
\end{tabular} & $\begin{array}{l}37.25^{\mathrm{B}} \pm \\
2.23\end{array}$ & $\begin{array}{l}35.58^{c} \pm \\
0.94\end{array}$ \\
\hline $60^{\text {th }}$ day & 82.94 & $\begin{array}{l}30.21 \pm \\
2.02\end{array}$ & \begin{tabular}{|l}
$28.58 \pm$ \\
1.40
\end{tabular} & \begin{tabular}{|l}
$27.78 \pm$ \\
0.67
\end{tabular} & $\begin{array}{l}34.27^{\mathrm{B}} \\
\pm 1.63\end{array}$ & $\begin{array}{l}34.96^{\mathrm{B}} \pm \\
0.99\end{array}$ & $\begin{array}{l}34.67^{c} \pm \\
0.39\end{array}$ & $\begin{array}{l}29.10^{A} \\
\pm 1.77\end{array}$ & $\begin{array}{l}28.45^{A} \pm \\
1.02\end{array}$ & $\begin{array}{l}25.80^{A} \pm \\
0.59\end{array}$ \\
\hline
\end{tabular}

Means bearing same superscript within a columns $(A-C)$ do not differ significantly $(p<0.05) \quad(n=6)$

al. (2015) and Habibu et al. (2017), where they found higher TLC levels with an elevated THI. As leucocytes are engaged in immune system, under thermal stress the immune system becomes activated (Okoruwa, 2014), thereby increasing the TLC.

In the present study, in Attappady black goats, mean TLC levels on $2^{\text {nd }}$ day were increased and then steadily decreased when THI was high suggesting a partial adaptation to the heat stressed conditions. Whereas, crossbred goat breeds maintained a steady
TLC level during entire study period, showing that the stress had not affected the immune functions. In the case of Malabari goats there was a drastic change in TLC indicating heat stress induced immune system activation.

\section{Haemoglobin (Hb)}

Significant difference in $\mathrm{Hb}$ concentration was not observed between breeds. However, mean $\mathrm{Hb}$ level was significantly increased in Crossbred goats and Attappady black goats when IT and THI were at 
peak. At the same time Malabari goats showed statistically non significant difference in $\mathrm{Hb}$ concentration which might be due to relatively decreased number of RBCs in Malabari goats on the $32^{\text {nd }}$ day. The observation was in accordance with Alam et al. (2011), Bhatta et al. (2014), Okoruwa (2014) and Habibu et al. (2017) who found an elevated $\mathrm{Hb}$ in goats in the afternoon than in the morning which could be due to high demand for oxygen which in turn necessitated high concentration of red blood cells to support respiratory activity under heat stress condition.

\section{Volume of Packed Red Cells (VPRC)}

No significant difference was noticed among the VPRC levels in breeds in the experimental period. A lower VPRC levels were recorded in breeds during high IT and THI. Observations of Abdelatif etal.(2009) supported the present study who recorded the decrease in VPRC in Nubian goats during summer which might be due to the lowered thyroid hormone levels in summer and that would be affecting the synthesis of RBCs as thyroid hormone level was crucial for erythropoiesis.

\section{Mean Corpuscular Volume (MCV)}

Significant difference was not observed between the breeds. A steady increase in MCV value was noticed in Attappady black goats from $2^{\text {nd }}$ day whereas in Malabari goats and crossbred goats from $32^{\text {nd }}$ day onwards. This emphasised the fact that adaptational alterations in volume of RBC were taking place most effectively in Attappady black goats compared to other two breeds to counteract the numerical changes in the RBC or to increase the $\mathrm{O}_{2}$ carrying capacity. This was in agreement with the findings of Abdelatif et al. (2009) who found a decreased MCV values during summer which could be related to the inverse relationship of number and volume of erythrocytes.

\section{Mean corpuscular haemoglobin concentrations (MCHC)}

No significant difference was noticed in $\mathrm{MCHC}$ levels between breeds. A higher $\mathrm{MCHC}$ level was recorded in all breeds during high THI. The MCHC had increased during peak summer to meet the increased $\mathrm{O}_{2}$ demand of the body. Similarly, Olayemi et al. (2015) found an increased level of $\mathrm{MCHC}$ in goats during summer. The results of the study indicated that the average erythrocyte cell size and haemoglobin content per erythrocyte were influenced by the $\mathrm{THI}$ and the amount of $\mathrm{Hb}$ relative to the size of the cell increased with increase in THI.

\section{Conclusion}

The mean TLC showed an increasing trend for Malabari goats during the entire experimental period. The mean $\mathrm{Hb}$ levels were significantly increased in all the breeds when IT and THI were at peak on $32^{\text {nd }}$ day indicating increased oxygen demand due to thermal stress. The MCV values were significantly lowered in Attappady black and $\mathrm{MCHC}$ values were increased in all the animals from $2^{\text {nd }}$ to $32^{\text {nd }}$ day of study indicating adaptive alterations in the haemogram suggestive of the impact of impact of thermal stress

\section{Acknowledgement}

The authors are grateful to the Kerala Veterinary and Animal Sciences University for providing the research facilities to complete this study.

\section{Conflict of interest}

The authors declare that they have no conflict of interest.

\section{References}

Abdelatif, A.M., Ibrahim, M. Y. and Hassan, Y. Y. 2009. Seasonal variation in erythrocytic and leukocytic indices and serum proteins in female Nubian goats. Middle E. J.Sci. Res. 4(3): 168-174.

Alam, M. M., Hashem, A., Rahmam, M. M., Hossain, M. M., Haque, M. R., Sobham, Z. and Islam, M. S. 2011. Effect of heat stress on behavior, physiological and blood parameters of goats. Prog. Agri. 22 (1\&2): 37-45.

Banerjee, D., Upadhyay, R.C., Chaudhary, U.B., Kumar, R., Singh, S., Ashutosh, Das, T.K. and De, S. 2015. Seasonal variations in physio-biochemical profiles of Indian goats in the paradigm of hot and cold climate. Biol. Rhythm res. 46(2): 221236

Bhatta, M., Das, D. and Ghosh, P.R. 2014. The effect of ambient temperature on some 
biochemical profiles of Black Bengal goats (Capra aegagrus hircus) in two different agro- climatic zones in West Bengal, India. IOSR J. Pharma. Biol. Sci. 9(4): 32-36.

Habibu, B., Kawu, M.U., Aluwong, T. and Makun, H.J.2017. Influence of seasonal changes on physiological variables, haematology and serum thyroid hormones profile in male Red Sokoto and Sahel goats. J. Appl. Anim. Res. 45(1): 508-516.

Harikumar, S. 2017. Behavioural, physiological and biochemical stress responses of crossbred cows to varying thermal indices in different management systems. PhD thesis, Kerala Veterinary and Animal Sciences University, Mannuthy, 47-50p.

Hassan, D.I., Musa-Azara, I.S., Mohammed, J. and Zanwa, I.A. 2013. Influence of age, sex and season on haematology and serum chemistry of Red Sokoto goats in Lafia, Nasarawa State Nigeria. Int. J. Agric. Sci. Vet. Med. 1: 4.

ICAR (Indian Council of Agricultural Research) 2013. Nutrient requirements of Animals - sheep, goat and rabbit. ( $3^{\text {rd }} \mathrm{Ed}$.). Indian Council of Agricultural Research, New Delhi, 28p.

IPCC (Intergovernmental Panel on Climate Change) 2018. Global Warming of $1.5^{\circ} \mathrm{C}$ : An IPCC Special Report on the impacts of global warming of $1.5^{\circ} \mathrm{C}$ above preindustrial levels and related global greenhouse gas emission pathways, in the context of strengthening the global response to the threat of climate change, sustainable development, and efforts to eradicate poverty. In: Masson-Delmotte, V., Zhai, P., Pörtner, H.O., Roberts, D., Skea, J., Shukla, P.R., Pirani, A., Moufouma-Okia, W., Péan, C., Pidcock, R., Connors, S., Matthews, J.B.R., Chen, Y., Zhou, X., Gomis, E. Lonnoy, M.I., Maycock, T., Tignor, M. and Waterfield T. (Eds.).

Jisha, N.V., Girish, V.G., Gleeja, V.L., Prasad, A., Beena, V., Karthiayini, K. and Sejian, V. 2021. Annual temperature profile of
Thrissur: A climate change perspective. J. Vet. Anim. Sci. 52(1): 26-31. DOI: h t t ps://doi .org/10.51966/ jvas.2021.52.1.26-31

LPHSI 1990. Livestock and poultry heat stress indices. The livestock and poultry heat stress indices for cattle, sheep and goats. Cited in the agriculture engineering technology guide, Clemson University, Clemson, SC, USA.

Mishra, R.P. 2009. Role of housing and management in improving productivity efficiency of goats. Goat productionprocessing of milk and meat. Central Institute for Research on Goats (CIRG), India. 45.

Okoruwa, M. I. 2014. Effect of heat stress on thermoregulaton, live body weight and physiological responses of dwarf goats in Southern Nigeria. Eur. Sci. J. 10(27): $1857-7431$.

Olayemi, O.D., Jegede, O.C., Obudu, E. and Obeta, S.S. 2015. Effect of dry and wet seasons on some haematological parameters in Sokoto Redgoat and Balami sheep. Vom J. Vet. Sci. 10: 96103.

Schalm, O. W., Jain, N. C. and Carroll, E. J. 1986. Veterinary Haematology. (4 $\left.4^{\text {th }} \mathrm{Ed}\right)$. Lea and Febiger, Philadeiphia. 45-48p.

Silanikove, N. 2000. The physiological basis of adaptation in goats to harsh environments. Small Rum. Res. 35: 181193.

Silanikove, N. and Koluman, N. 2015. Impact of climate change on the dairy industry in temperate zones: predications on the overall negative impact and on the positive role of dairy goats in adaptation to earth warming. Small Rum. Res. 123: 27-34.

Zarina, A. 2016. Adaptability profile of male cattle and buffalo calves to varying Temperature Humidity Index (THI) in Kerala.PhD thesis, Kerala Veterinary and Animal Sciences University, Mannuthy, $135 p$. 